\title{
Kontaminasi Residu Pestisida Organoposfat: Klorpirifos, Fenitrotion dan Profenofos dalam Bivalvia yang Ditangkap di Pesisir Utara Pulau Jawa
}

\author{
Chrisna Adhi Suryono*, Agus Sabdono dan Subagiyo \\ Departemen IImu Kelautan, Fakultas Perikanan dan IImu Kelautan, Universitas Diponegoro \\ JI. Prof Soedarto, SH. Kampus UNDIP Tembalang Semarang 50275 \\ Email: chrisna_as@yahoo.com

\begin{abstract}
The Contamination of Organophosphate Pesticide Residues: Chlorpyrifos, Fenitrothion and Profenofos in Bivalves Which was Fishing in The North Coast of Java
\end{abstract}

Organophosphate pesticides were widely used in agriculture and OPP which was less accumulative and degradable but It has been found in an aquatic environment. The purpose of this study was to determine the level of organophosphate pesticide residues in bivalve which was fishing in North Coast of Java specifically the Demak and Surabaya. Bivalvia, sediment and seawater samples were analysed using GC-MS. The results showed that the bivalves of $A$ inaequivalvis, $P$ viridis, A pectinata captured in Demak and Surabaya were contaminated with organophosphate pesticide of chlorpyrifos, fenitrothion and profenofos. The chlorpyrifos was found in all species of bivalves, but the highest concentrations of OPP were profenophos> chlorpyrifos > fenitrothion respectively. ANOVA test results show that there was a very significant difference in OPP residues in bivalves $p=0.009$, but there was no difference in OPP residues between locations.

Keywords: Organophosphate pesticides; bivalve; contamination; residues

\begin{abstract}
Abstrak
Organoposfat pestisida (OPP) banyak digunakan secara melvas dalam pertanian dan OPP tersebut kurang akumulatif dan mudah terurai namun keberdaanya telah di temukan dala lingkungan perairan. Tujuan dari penelitian adalah untuk mengetahui tingkat akumulasi residu pestisida organoposfat yang terdapat di bivalvia yang ditangkap di pesisir Utara Jawa khususnya wilayah Demak dan Surabaya. Sampel bivalvia, sedimen dan air laut dianalisa menggunakan GCMS. Hasil penelitian menunjukan bahwa bivalvia $A$ inaequivalvis, $P$ viridis, A pectinata yang ditangkap di Demak dan Surabaya terkontaminasi pestisida organoposfat jenis Klorpirifos, Fenitrotion dan Profenofos. Klorpirifos ditemukan pada semua bivalvia, namun konsentrasi tertinggi OPP secara berurutan profenofos $>$ klorpirifos $>$ fenitrotion. Hasil uji ANOVA menunjukan adanya perbedaan yang sangat nyata residu OPP dalam bivalvia $p=0.009$, namun tidak ada berbedaan residu OPP antar wilayah lokasi.
\end{abstract}

Kata Kunci : Pestisida Organoposfat; bivalvia; kontaminasi; residu

\section{PENDAHULUAN}

Pestisida organoposfat (OPP) adalah kelompok bahan kimia yang sangat beracun yang banyak digunakan dalam bidang pertanian untuk mengendalikan berbagai jenis serangga (Zhang et al., 2006). Namun penggunaan pestisida ini menimbulkan kekawatiran di seluruh dunia karena efek dari kontaminasi yang terbawa oleh aliran sungai
(Xing et al., 2015). Hal tersebut dikarenakan telah ditemukan residu OPP pada priduk peternakan dan perikanan (Fu et al., 2004) dan telah mencemari ekosistem sebagai zat beracun (Tang et al., 2015). Residu OPP diduga telah sampai ke lingkungan laut, terutama pada wilayah yang banyak dialiri sungai seperti perairan pantai Utara Jawa sekitar Pulau Jawa seperti Demak dan Surabaya. Dimana hulu dari beberapa sungai 
yang mengalir ke daerah tersebut merupakan daerah pertanian dan perkebunan yang menggunakan OPP.

Beberapa penelitian yang telah dilakukan terhadap kontaminasi residu OPP di Indanesia terfokus pada hasil pertanian seperti sayuran. Analisis Residu Klorpirifos Pada sawi hijau (Marzuki dkk, 2014), tanah sayuran kubis (Sulaeman dkk, 2016), tanah dan produk bawang merah (Harsanti dkk, 2015). Namun sudah ada penelitian di beberapa negara lain yang telah meneliti OPP dalam lingkungan laut. Kontaminasi OPP pada air laut, partikel tersuspensi dan sedimen di lingkungan laut di Laut Tengah dengan melihat (Montuori, et al, 2016). Pestisida organoposfat (Klorpirifos) berdampak pada perkembangan larva artemia (Gambardella et al, 2018). Demikian pula jenis OPP (azametifos) menyebabkan kematian terhadap $M$. edulis (Canty et al, 2017). Efek toksikologi OPP terhadap perkembangan larva ikan sebra memberi dampak yang suknifikan (Sun et al 2016). Beberapa jenis pestisida juga telah ditemukan dalam rumput laut salah satunya pestisida organoposfat (Rodríguez et al, 2012). Pada prinsipnya pestisida organoposfat telah menyebar kebarbagiai ekosistem dan biota yang ada di lautan. Monitoring variasi musiman terhadap OPP yang terdapat dalam atmosfir, tanah dan air juga telah di lakukan di China (Li et al, 2014). Dari informasi diatas dicurigai bahwa organisme benthik yang terdapat di perairan Indonesia diduga juga telah terkontaminasi oleh OPP dikarekanan penggunaan pestisida terebut yang sangat massif. Tujuan dari penelitian ini adalah untuk mengetahui tingkat akumulasi residu pestisida organoposfat yang terdapat di bivalvia yang ditangkap di pesisir Utara Jawa khususnya Demak dan Surabaya.

\section{MATERI DAN METODE}

Sampel bivalvia diambil di sekitar perairan di pesisir Utara Jawa khususnya Demak dan Surabaya (Gambar 1) dengan menggunakan drager dengan ulangan sebanyak empat kali. Sampel sedimen diambil dengan menggunakan ekman grap dan air laut menggunakan water botle sampler. Bivalvia yang didapat dikumpulkan berdasarkan jenisnya dan dipisahkan dagingnya untuk keperluan analisa organoposfat di laboratorium. Analisa pestisida organoposfat sampel sedimen, air laut dan jaringan bivalvia menggunakan GCMS (kromatografi gas). Ektraksi dan analisa organoposfat dalam bivalvia sedimen dan air laut mengacu pada protokol (DFG, 1982; Dauberschmidt et al., 1997; Suryono et al., 2019). Sampel padat bivalvia ditumbuk dan cairan dikeringkan dan dibuang. Jaringan yang terkumpul 2 -10 bivalvia digiling dengan enam kali berat natrium sulfat anhidrat dengan mortar hingga homogen. Homogenan diekstraksi dengan refluks tiga kali selama 10 menit dengan $50 \mathrm{ml}$ petroleum benzene. Ekstrak petroleum benzene divapkan dalam keadaan vakum sampai kering dan residunya diambil dalam nheksana $(1 \mathrm{ml}$ atau $100 \mu \mathrm{l})$. Ekstrak minyak benzena divapkan dalam keadaan vakum sampai kering. Residunya diambil dalam $1 \mathrm{ml}$ n-heksana.

\section{HASIL DAN PEMBAHASAN}

Hasil analisa pestisida organoposfa (OPP) terhadap bivalvia, sedimen dan air laut terhadap sampel yang diambil di sekitar

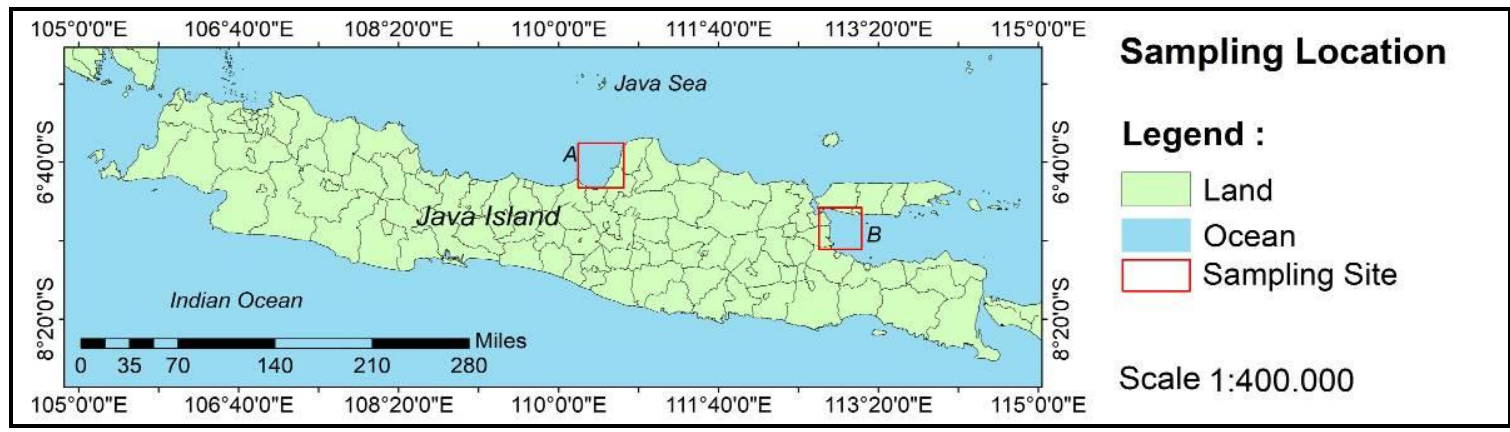

Gambar 1. Lokasi Pengambilan Sampel Bivalvia di sekitar Pesisir Demak dan Surabaya 
perairan Demak dan Surabaya ditemukan OPP dari jenis Klorpirifos, Profenofos dan Fenitrotion dari tiga jenis bivalvia (Anadara inaequivalvis, Perna viridis dan Atrina pectinata) sedangkan OPP yang terdapat pada sedimen dan air laut kesemuanya menunjukan konsentrasi yang sangat rendah yang tidak terbaca oleh standar alat $(b d)$ (Gambar 2 dan Tabel 1).

Sebenarnya dalam penelitian ini didapatkan berbagai jenis bivalvia di kedua daerah tersebut namun yang terkontaminasi hanya ketiga jenis tersebut. Jenis A inaequivalvis didapatkan di kedua daerah yang terkontaminasi OPP (Klorpirifos dan Profenofos). Sedangkan $P$ viridis yang terkontaminasi OPP hanya didapat perairan sekitar Demak yang terkontaminasi OPP (Klorpirifos dan Fenitrotion). A pectinata hanya didapat di perairan Surabaya dan terkontaminasi OPP (Klorpirifos dan Fenitrotion). Sebenarnya OPP merupakan pestisida yang tidak persisten di alam namun dengan penggunaan yang sangat luas dan terus menerus menyebabkan residu OPP tersebut selalu ada di lingkungan. Selama sepuluh tahun terakir pestisida organofosfat (OPP) lebih banyak digunakan dibandingkan dengan pestisida organoklorin (OCP) diseluh dunia (Montuori et al 2016). Karena pestisida organoklorin (OCP) bersifat persisten dan merusak lingkungan (Zheng et al., 2016; Yu et al., 2016), sedangkan OPP rusak lebih cepat di lingkungan, memiliki dampak yang lebih ringan dan lebih aman dan kurang persisten. Diperkirakan bahwa OPP beredar hampir $40 \%$ dari pasar global pestisida. OPP paling populer dan penggunaannya masih terus berkembang, terutama karenamurah, spektrum aplikasi yang luas, kemampuan pengendalian multi-hama dan kurangnya resistensi hama (Dujaković et al., 2010; Li et al., 2010; Sapbamrer \& Hongsibsong, 2014). Maka dari hal tersebut OPP menngontaminasi organisme laut termasuk berbagai jenis bivalvia yang ada di Demak dan Surabaya, karena OPP juga digunakan secara luas di pertanian dan tambak.

Pestisida organoposfat jenis Klorpirifos ditemukan pada semua bivalvia yang ditemukan di kedua daerah penelitian. Hal tersebut menunjukan bahwa Klorpirifos banyak digunakan secara meluas. Hal tersebut juga telah dibuktikan dengan masih ditemukannya residu insektisida klorpirifos pada tanah, air, dan tanaman (Ardiwinata 2008) dan insektisida klorpirifos juga ditemukan di tanah pada tanaman padi (Ardiwinata et al., 1999). Akir dari semua polutan yang ada didaratan seperti pestisida akan berakir di lautan bila tidak terjadi degradasi, hal inilah yang menyebabkan klorpirifos ditemukan dalam bivalvia di pesisir Demak dan Surabaya.

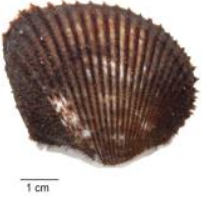

A. inaequivalvis

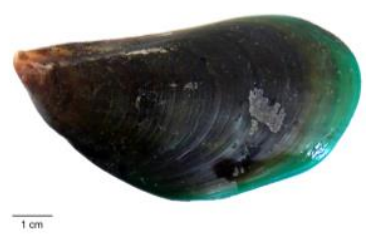

$P$. viridis

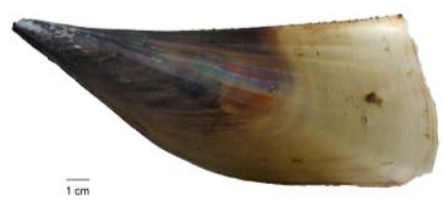

A. pectinata

Gambar 2. Jenis-jenis Bivalvia yang terkontaminasi pestisida organoposfat.

Tabel 1. Rata rata \pm sd konsentrasi pestisida organoposfat pada bivalvia, sedimen dan air laut yang ditangkap disekitar perairan Demak dan Surabaya

\begin{tabular}{lcccccc}
\hline \multirow{2}{*}{ Bivalvia } & \multicolumn{3}{c}{ Demak } & \multicolumn{3}{c}{ Surabaya } \\
\cline { 2 - 7 } & Klorpirifos & Profenofos & Fenitrotion & Klorpirifos & Profenofos & Fenitrotion \\
\hline A. inaequivalvis & $0.063 \pm 0.02$ & bd & bd & $0.421 \pm 0.09$ & $1.497 \pm 0.19$ & bd \\
P. viridis & $0.221 \pm 0.15$ & bd & $0.413 \pm 0.03$ & bd & bd & bd \\
A. pectinata & - & - & - & $0.097 \pm 0.04$ & bd & $0.046 \pm 0.01$ \\
\hline Sedimen & bd & bd & bd & bd & bd & bd \\
\hline Air laut & bd & bd & bd & bd & bd & bd \\
\hline
\end{tabular}

Keterangan : bd = konsentrasi sangat rendah tidak terukur oleh instrumen; - = tidak didapatkan bivalvia jenis tersebut di lokasi 


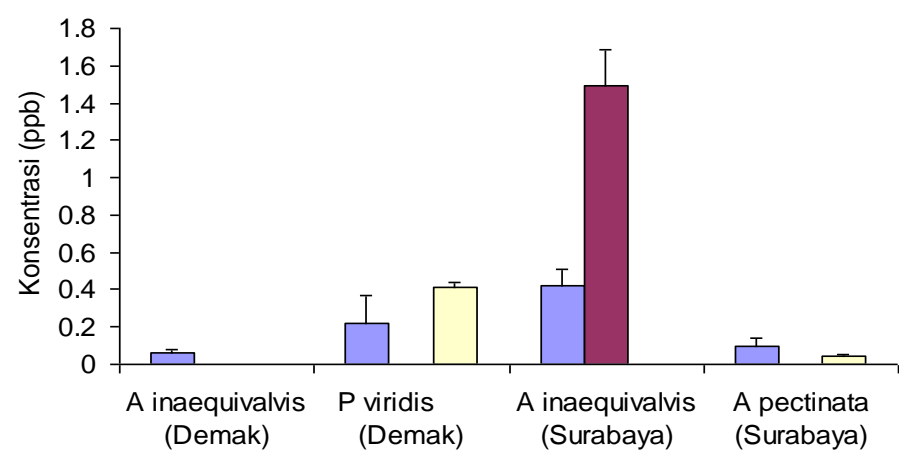

Jenis kerang dan Asal

$\square$ Klorpirifos $\quad \square$ Profenofos $\quad \square$ Fenitrotion

Gambar 3. Konsentrasi \pm sd dan Sebaran Pestisida organoposfat pada Bivalvia di Demak dan Surabaya

Gambar 3 menunjukan bahwa tidak jenis OPP ditemukan di dalam bivalvia yang ada di perairan Surabaya seperti Klorpirifos, Profenofos dan Fenitrotion sedangkan bivalvia yang diambil dari Demak hanya ditemukan jenis Klorpirifos dan Fenitrotion. Konsentrasi tertinggi OPP yang ditemukan dari jenis Profenofos yang terdapat di bivalvia A inaequivalvis dari Surabaya. Hasil uji one way ANOVA terhadap residu Klorpirifos, Profenofos, Fenitrotion yang terdapat di bivalvia $(p=0.009 \leq 0.01)$ yang mengindikasikan adanya perbedaan yang sangat nyata antar ketiga organoposfat tersebut dalam bivalvia. Sedangkan uji yang sama terhadap residu Klorpirifos, Profenofos, Fenitrotion pada dua daerah yang berbeda Demak dan Surabaya $(p=0.520 \geq 0.05)$ menunjukan bahwa dikedua daerah tersebut tidak menunjukan adanya perbedaan. Hal tersebut mengindikasikan bahwa daerah tidak memberi pengaruh terhadap besar kecilnya residu atau banyak sedikit jenis OPP namun yang paling penting adalah kontiunitas supllai residu OPP kedalam wilayah tersebut dan kelancaran arus air laut yang dapat mencuci daerah tersebut dari residu pestisida. Aktivitas antropogenik yang berkembang pesat di sepanjang wilayah pesisir dan masukan berbagai senyawa kimia meningkatkan sensitivitas ekosistem laut. Diantaranya adalah OPP yang digunakan secara luas (Perić et al., 2013). Meskipun OPP cepat terdegradasi dalam perairan dan biota, dan dianggap sebagai bahan kimia persisten rendah. Namun kekhawatiran tetap ada pada organisme non-target terutama di daerah pesisir yang disebabkan oleh sirkulasi air yang buruk dan selama periode kegiatan intensip pertanian (Kirby et al., 2000; Solé et al., 2000). Pestisida organoposfat berpotensi berbahaya bagi organisme perairan karena efek penghambatan yang berkepanjangan pada aktivitas enzim cholinesterase (ChE) (Coelho et al., 2011; Valbonesi et al., 2011) dan kemampuan untuk menginduksi gangguan fisiologis lainnya (Xuereb et al., 2009; Almeida et al., 2010). Selain itu paparan pestisida terhadap spesies perairan yang tidak disengaja dapat menimbulkan risiko bagi kesehatan manusia (Valbonesi et al., 2011).

\section{KESIMPULAN}

Kesimpulan dari penelitian ini adalah tidak ditemukan pestisida organophospat pada sedimen dan air, namun ditemukan pada bivalvia. OPP dari jenis Klorpirifos ditemukan pada semua bivalvia, namun konsentrasi tertinggi OPP secara berurutan profenofos $>$ klorpirifos $>$ fenitrotion. Hasil uji ANOVA menunjukan adanya perbedaan yang sangat nyata residu OPP dalam bivalvia $\mathrm{p}=0.009$, namun tidak ada berbedaan residu OPP antar wilayah lokasi.

\section{UCAPAN TERIMAKASIH}

Artikel ini merupakan bagian dari penelitian Disertasi S3 program Doktor IImu Kelautan Fakultas Perikanan dan IImu Kelautan Universitas Diponegoro, Semarang 


\section{DAFTAR PUSTAKA}

Almeida, J.R., Oliveira, C., Gravato, C., \& Guilhermino, L., 2010. Linking behavioural alterations with biomarkers responses in the European seabass Dicentrarchus labrax L. exposed to the organophosphate pesticide fenitrothion. Ecotoxicology, 19(8):1369-1381.

Ardiwinata, A.N. 2008. Peran karbon aktif dalam proses degradasi residu karbofurani di tanah oleh mikroba. Prosiding Seminar Nasional Pengendalian Pencemaran Lingkungan Pertanian Melalui Pendekatan Pengelolaan Daerah Aliran Sungai (DAS) Secara Terpadu. Surakarta 28 Maret 2006. Balai Penelitian dan Pengembangan Sumberdaya lahan Pertanian. 171-189 pp

Ardiwinata, A.N., Jatmiko, S.Y., \& Harsanti, E.S. 1999., Monitoring residu insektisida di Jawa Barat. Risalah seminar hasil penelitian emisi gas rumah kaca. Pusat Penelitian dan Pengembangan Tanaman Pangan. Bogor. $15 \mathrm{p}$

Canty, M.N., Hagger, J.A., Moore, R.T.B., Cooper, L. \& Galloway, T.S., 2017., Sublethal impact of short term exposure to the organophosphate pesticide azamethiphos in the marine mollusc Mytilus edulis. Marine Pollution Bulletin. 54, 396-402, doi: 10.1016/j.marpolbul.2006.11. 013

Coelho, S., Oliveira, R., Pereira, S., Musso, C., Domingues, I., Bhujel, R.C., Soares, A.M.V.M., \& Nogueira, A.J.A., 2011 ., Assessing lethal and sub-lethal effects of trichlorfon on different trophic levels. Aquatic Toxicology, 103(3-4):191-198.

Dauberschmidt, C., Dietrich, D.R., \& Schlatter, C., 1997., Organophosphates in the Zebra Mussel Dreissena polymorpha: Subacute Exposure, Body Burdens, and Organ Concentrations, Archives of Environmental Contamination and Toxicology, 33:42-46

DFG., 1982., Organochlor und organophosphor pestizide. In: Deutsche Forschungsgemeinschaft (ed) Ruckstandsanalytik von Pflanzenschutzmittel. Verlag Chemie, Weinheim, pp 1-13

Dujaković, N., Grujić, S., Radisić, M., Vasiljević, T., \& Lausević, M., 2010. Determination of pesticides in surface and ground waters by liquid chromatography-electrospraytandem mass spectrometry. Analytica Chimica Acta, 678(1):63-72. doi: 10.1016 j.aca.2010.08.016

Fu, G., Cui, Z., Huang, T., \& Li, S., 2004. Expression, purification, and characterization of a novel methyl parathion hydrolase. Protein Expression and Purification. 36:170-176. doi: 10.1016/ j.pep.2004.04.019.

Gambardella, C., Nichino, D., lacometti, C., Ferrando, S., Falugi, C \& Faimali, M., 2018., Long term exposure to low dose neurotoxic pesticides affects hatching, viability and cholinesterase activity of Artemia sp. Aquatic Toxicology. 196:7989. doi: 10.1016/j.aquatox.2018.01.006

Harsanti, E.S., Martono, E., Sudibyakto, H.A., \& Sugiharto, E., 2015., Residu insektisida Klorpifos dalam Tanah dan Produk Bawang Merah Allium ascalonicum L, di Sentra Produksi Bawang di Kabupaten Bantul Yogyakarta. Ecolab. 9(1):26-35

Kirby, M.F., Morris, S., Hurst, M., Kirby, S.J., Neall, P., Tylor, T., \& Fagg, A., 2000. The use of cholinesterase activity in flounder (Platichthys flesus) muscle tissue as a biomarker of neurotoxic contamination in UK estuaries. Marine Pollution Bulletin, 40, 780-791

Li, H., Ma, H., Lydy, M.J. \& You, J., 2014. Occurrence, seasonal variation and inhalation exposure of atmospheric organophosphate and pyrethroid pesticides in an urban community in South China, Chemosphere, 95:363-369. doi: 10.1016/j.chemosphere.2013.09.046

Li, X., Gan, P., Peng, R., Huang, C., \& Yu, H., 2010. Determination of 23 organophosphorous pesticides in surface water using SPME followed by GC-MS. Journal of Chromatographic Science. 48 (3):183-187.

Marzuki, A., Naid, T., \& Risky, S., 2014. Analisis residu klorpirifos pada sawi hijau (Brassica Rapa Var.Parachinensis L.) terhadap parameter waktu Retensi metode kromatografi gas. Pharmacon, 3(4):133143

Montuori, P., Aurino, S., Garzonio, F., Sarnacchiaro, P., Polichetti, S., Nardone, A., \& Triass, M., 2016., Estimates of Tiber River organophosphate pesticide loads to the Tyrrhenian Sea and ecological risk. 
Science of the Total Environment, 559: 218-231. doi: 10.1016/j.scitotenv.2016.03. 156

Perić, L., Ribarić, L. \& Nerlović, V., 2013. Cholinesterase activity in the tissues of bivalves Noah's ark shell (Arca noae) and warty venus (Venus verrucosa): Characterisation and in vitro sensitivity to organophosphorous pesticide trichlorfon. Comparative Biochemistry and Physiology Part B: Biochemistry and Molecular Biology, 165(4):243-249. doi: 10.1016/j.cbpb.2013.05.002

Rodríguez, D.G., Torrijos, R.C., Ferreira, L. \& Díaz, A.M.C., 2012., Analysis of pesticide residues in seaweeds using matrix solidphase dispersion and gas chromatography-mass spectrometry detection. Food Chemistry, 135:259-267, doi: 10.1016/j.foodchem.2012.04.088

Sapbamrer, R., \& Hongsibsong, S., 2014. Organophosphorus pesticide residues in vegetables from farms, markets, and a supermarket around Kwan Phayao Lake of northern Thailand. Arch. Environ. Contam. Toxicol. 67(1):60-67. doi: 10.100 7/s00244-014-0014-x.

Solé, M., Porte, C., Barcelo, D., \& Albaiges, J., 2000. Bivalves residue analysis for the assessment of coastal pollution in the Ebro Delta (NW Mediterranean). Marine Pollution Bulletin, 40(9):746-753.

Sulaeman, E., Ardiwinata, A.N \& Yani, M., 2016., Eksplorasi bakteri pendegradasi insektisida klorpirifos di tanah sayuran kubis di Jawa Barat. Jurnal Tanah dan Iklim 40(2):103-112

Sun, L., Xu, W., Peng, T., Chen, H., Ren, L., Tan, H., Xiao, D., Qian, H., \& Fu, Z., 2016., Developmental exposure of zebrafish larvae to organophosphate flame retardants causes neurotoxicity. Neurotoxicology and Teratology, 55:1622, doi: 10.1016/j.ntt.2016.03.00

Suryono, C.A., Sabdono, A., Subagiyo \& Setyati, W.A. 2019. The Preliminary Investigation of Organophosphate Pesticide Residues on Green Mussel Perna viridis (bivalvia: Mytilidae, linnaeus, 1758) at Demak Coastal Waters Central
Java Indonesia. IOP Conf. Ser.: Earth Environ. Sci. 246 012071. doi: 10.1088/1755 $-315 / 246 / 1 / 012071$

Tang, X., Liang, B., Yi, T., Manco, G., Palchetti, I., \& Liu, A., 2015. Cell surface display of organophosphorus hydrolase for sensitive spectrophotometric detection of pnitrophenol substituted organophosphates. Enzyme and Microbial Technology, 55:107-112. doi: 10.1016/j.enzmictec.2013.10.006

Valbonesi, P., Brunelli, F., Mattioli, M., Rossi, T., \& Fabbri, E., 2011. Cholinesterase activities and sensitivity to pesticides in different tissues of silver European eel, Anguilla Anguilla. Comparative Biochemistry and Physiology, 154(4):353359.

Xing, H., Wang, Z., Wu, H., Zhao, X., Liu, T., Li, S., \& Xu, S., 2015. Assessment of pesticide residues and gene expression in common carp exposed to atrazine and chlorpyrifos: health risk assessments. Ecotoxicology and Environmental Safety, 113:491-498. doi: 10.1016/j.ecoenv.2014. 12.040

Xuereb, B., Lefèvre, E., Garric, J. \& Geffard, O., 2009. Acetylcholinesterase activity in Gammarus fossarum (Crustacea Amphipoda): linking AChE inhibition and behavioural alteration. Aquatic Toxicology, 94(2):114-122.

Yu, R., Liu, Q., Liu, J., Wang, Q., \& Wang, Y., 2016. Concentrations of organophosphorus pesticides in fresh vegetables and related human health risk assessment in Changchun, Northeast China. Food Control, 60:353-360. doi : 10.1016/j.food cont.2015.08.013.

Zhang, Z., Hong, Q., XU, J., Zhang, X., \& Li, S., 2006. Isolation of fenitrothion-degrading strain Burkholderia sp. FDS-1 and cloning of mpd gene. Biodegradation 17:275283. doi: $10.1007 / \mathrm{s} 10532-005-7130-2$.

Zheng, S., Chen, B., Qiu, X., Chen, M., Ma, Z., \& Yu, X., 2016. Distribution and risk assessment of 82 pesticides in Jiulong River and estuary in South China. Chemosphere, 144:1177-1192. doi: 10.10 16/j.chemosphere.2015.09.050. 